\title{
Kidney Histopathology of Gallus gallus domesticus Infected by $E$. coli in Denpasar, Bali
}

\author{
Ni Kadek Prederika Sari Andayani, Iriani Setyawati* and Martin Joni \\ Biology Study Program, Faculty of Mathematics and Natural Sciences, Udayana University \\ Bukit Jimbaran Campus, Badung, Bali \\ *Corresponding author: iriani_setyawati@unud.ac.id
}

\begin{abstract}
One of the diseases that attacks poultry especially laying hens (Gallus gallus domesticus) is colibacillosis, a disease caused by Escherichia coli. E. coli is a bacterium that has opportunistic properties, which is normally present in the digestive tract in a controlled amount, but when the condition of the chicken decreases, it can develop into pathogens. Kidneys are organs that are vulnerable to substances that are toxic and are also susceptible to bacterial infections. This study aimed to determine the histological structure of kidneys of laying hens (Gallus gallus domesticus) who died due to the infection of E. coli. The research was conducted at a Pathology Laboratory (BBVet), Denpasar. The hen's kidneys were processed with the paraffin method and Hematoxylin-Eosin staining. Cell damage that occurs is observed by using the Image Raster application. The data obtained were analyzed with the scoring method. Renal histopathology parameters can be seen in the form of degeneration, necrosis, congestion, and inflammatory cell infiltration. The results obtained cell damages namely $46 \%$ of degeneration, $60 \%$ of necrosis, $44 \%$ of congestion and $76 \%$ of inflammatory cell infiltration.
\end{abstract}

Keyword: colibacillosis, Gallus gallus, histopathology, kidney

\section{INTRODUCTION}

Indonesia is a developing country, along with the increasing number of population, with an awareness of the importance of increasing nutrition quality in life. This has implications for food consumption patterns. Nowadays the development of poultry is developing very rapidly compared to other livestock and especially laying hens (Gallus gallus domesticus). Economically, the development of laying hens in Indonesia has a favorable business prospect because demand is always increase.

An important factor so that chickens on a farm can grow and produce optimally is the chickens on the farm must be in good health. The reality on the ground shows that although all aspects of animal husbandry management, namely DOC (Day Old Chicken), feed, maintenance systems, health programs, and product marketing systems have been managed optimally, often various diseases still occur. Based on the primary target, diseases in chickens can be classified as respiratory diseases, digestive diseases, immune system diseases and reproductive system diseases [1].

Laying hens is a chicken that is very efficient in producing eggs. Good management of laying hens will result in good chicken growth, healthy chicken conditions, low mortality rates and high egg production. Chicken disease is a major obstacle to chicken farming in tropical environments such as Indonesia. Economic losses due to diseases, especially infectious diseases, can be described in the form of death, stunted growth, decreased or completely stopped egg production. One of the urgent needs now is to determine the diseases that exist in chicken farms.

Colibacillosis is an infectious disease in poultry caused by pathogenic Escherichia coli $(E$. coli) bacteria as a primary or secondary agent. $E$. coli infections can occur in broilers and laying hens of all age groups, as well as other poultry such as turkeys and ducks [2]. Colibacillosis including five major diseases that often complicate with Gumboro, Newcastle Disease (ND), Salmonella pullorum and Chronic Respiratory Disease (CRD) [3].

The clinical signs of colibacillosis are not very specific and are influenced by the age of chickens, duration of infection, organs affected and other diseases with it. Broiler chickens aged 4-8 weeks and laying hens \pm 20 weeks can develop acute septicemia (complications) and cause death, which is preceded by loss of appetite, lazy to move or inactive and sleepy [4]. Transmission of colibacillosis usually occurs orally through food, drinking water, and dust or dirt contaminated by E. coli. Dust in chicken coops can contain $10^{5}-10^{6} \mathrm{E}$. coli per gram and this bacteria can last a long time, especially in dry conditions. If the dust is inhaled by chickens, it can infect the respiratory tract [1]. 
E. coli is a bacterium that has opportunistic properties, which is normally present in the digestive tract in a controlled amount, but when the condition of the chicken decreases, it can develop into pathogens. The part of the intestine that contains the most $E$. coli is jejenum, ileum, and cecum. The type of $E$. coli in the intestine is not always the same as the type found in other tissues.

\section{RESEARCH METHODS}

This research was carried out on January 2018. Necropsy and sample preservation was carried out in the Section Room; sectioning, staining, and mounting preparations were carried out in the Staining Room; and observation of the histological structure of the kidneys was carried out in the Histopathology Room; all rooms were part of the Pathology Laboratory of the Veterinary Center (BBVet) Denpasar.

Preparation of histological preparations was carried out by the paraffin method and Hematoxylin-Eosin staining. Observation of kidneys histology was carried out used an Olympus type BX 51 light microscope with magnifications of 200x and 400x. Cell damages or abnormalities were observed and calculated in each field of view under microscope observation and Image Raster application.

Data obtained from the results of this study were analyzed descriptively by scoring at the severity level. Scoring degree of damage or Histopathology Index in each sample was the total score of all forms of lesions that occured. The scoring technique used in this research was a modification of the Knodell method [5]. The degree of damage from each sample was determined by adding up all the histopathological lesion scores that have been determined. The forms of the lesions observed and the score of each lesion can be seen in Table 1 .

TABLE 1.

CATEGORIES AND ASSESSMENT OF ORGAN DAMAGE

\begin{tabular}{lcc}
\hline \multicolumn{1}{c}{ Damage Category } & Damage Percentage & Score \\
\hline Normal & $0 \%$ & 0 \\
Minor damage & $>0-25 \%$ & 1 \\
Moderate damage & $>25-50 \%$ & 2 \\
Severe damage & $>50-75 \%$ or more & 3 \\
\hline
\end{tabular}

\section{RESULTS AND DISCUSSION}

The histopathological identification of laying hen's kidneys resulted the percentage of cell damage namely $45 \%$ of cell degeneration, $60 \%$ necrosis, $44 \%$ of congestion and $76 \%$ of inflammatory cell infiltration in the kidneys as seen in Table 2.

TABLE 2.

CATEGORIES AND ASSESSMENT OF ORGAN DAMAGE

\begin{tabular}{lcl}
\hline \multicolumn{1}{c}{ Histopathology } & Percentage & Damage Category \\
\hline Cell degeneration & $45 \%$ & Normal \\
Necrosis & $60 \%$ & Minor damage \\
Congestion & $44 \%$ & Moderate damage \\
Inflammatory cell & $76 \%$ & Severe damage \\
infiltration & &
\end{tabular}

Note: Severity damage categories: normal (0\%), mild (1$24 \%)$, medium (25-74\%) and severe (75-100\%).
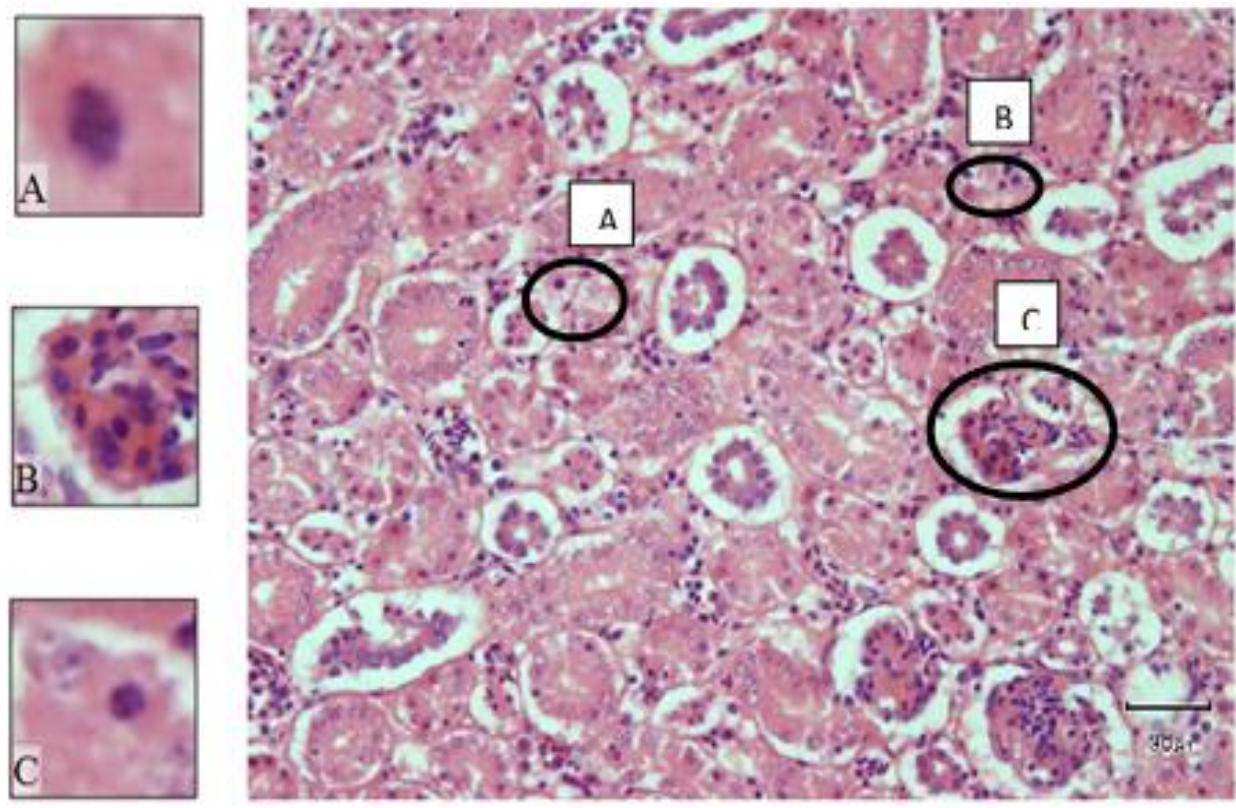

Fig.1. Kidneys histopathology of colibacillosis-infected laying hens A. Necrosis, B. Congestion, C. Degeneration (magnification 400x) 


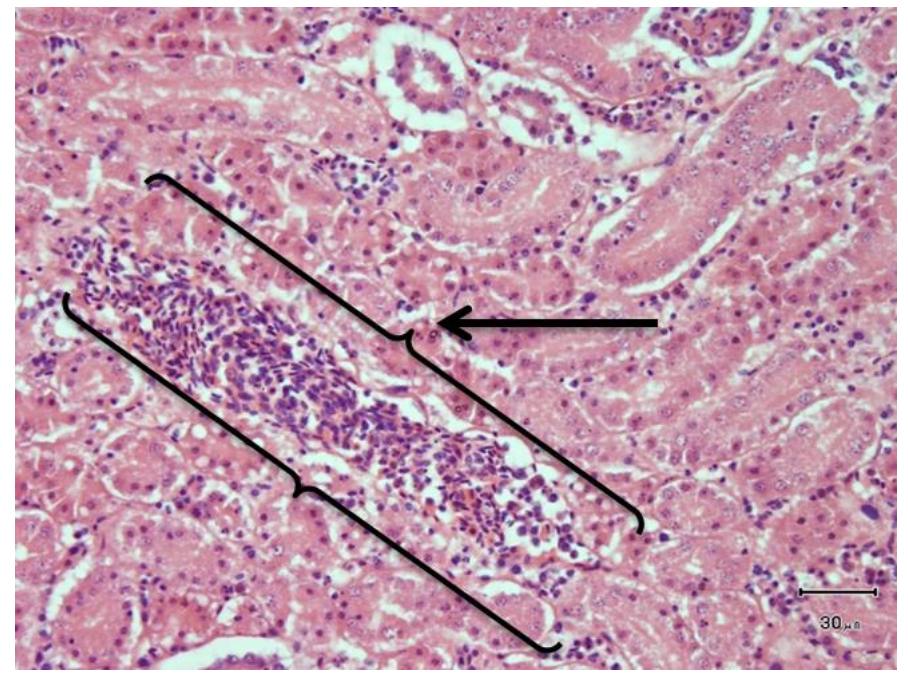

Fig.2. Inflammation cells infiltration in the kidneys of colibacillosis-infected laying hens (magnification 400x)

\section{Discussion}

Laying hens (Gallus gallus domesticus) are breeder chickens that are cultivated and have high economic value. The case numbers of chicken deaths causes a decrease in chicken production. In this observation, laying hens died due to infection with $E$. coli bacteria. This bacterial infection causes colibacillosis in chickens.

Poultry disease caused by $E$. coli bacteria is colibacillosis [6] that can be found in various forms. Chickens attacked by colibacillosis generally show clinical signs including thinness, dull feathers, decreased appetite, depressed and disrupted chicken growth, diarrhea, and dirty or sticky feathers around the cloaca [1]. Death most often occurs in 5 days old chicks [7].

Examination of kidney organs of laying hens (Gallus gallus domesticus) that died due to colibacillosis in the Experimental Animal Cage of the Veterinary Center, Denpasar, showed damage to the kidneys. The macroscopic organ of the kidneys have shown damage and blackish brown. Microscopically, there were damage in the form of cell degeneration and necrosis in the tubules and also congestion and inflammatory cell infiltration.

Kidney is a very important organ as excretion organ of metabolic waste. In the excretion process, the kidneys can experience damage because the excreted substances in the form of substances that are toxic to the body [8]. The main function of the kidneys is as an important eliminating organ for the body. Although there are many factors that affect the susceptibility of the kidneys to toxic effects, the high flow of cardiac output and an increase concentration of excretion products due to the reabsorption of water from tubular fluid are the most important factors [9].

Damage to kidney cells in laying hens were observed and calculated using the image raster application and the Knodell scoring method [5]. Histopathological observation showed damage in the form of cell degeneration with a percentage of $46 \%$ and categorized as moderate damage (Table 2, Fig.1). Degeneration is the loss of normal cell structure before cell death due to the presence of toxic substances. Hydropic degeneration occurs due to accumulation of extracellular fluid due to a disruption in the mechanism of sodium pumps which can be caused by ischemia (reduced blood flow to the tissue due to blockages or narrowing of blood vessels), abnormal metabolism, and chemicals [10].

The observations showed an average percentage of necrotic damage of $60 \%$ and categorized as moderate damage (Table 2, Figure 1). The observation of the kidney organs under the microscope, there are many pycnotic nucleus were found. The pycnotic nucleus is a condition in which the chromosomes in the nucleus change color to darkening, shrinking, and chromatin clumping [11].

Necrosis is tissue cell death due to injury when the individual is still alive. Microscopically, there is a change in the nucleus namely a loss of chromatin, becomes wrinkled, no longer vascular, appears denser and dark (pycnosis), divided into fragments (karyorrhexis), or dissapear of nucleus (karyolysis). Necrosis can be caused by various agents and can cause death. Causative agents of necrosis are strong poisons (arsenic and other poisonous phosphorus fungi) and metabolic disorders (usually in protein metabolism). Viral and bacterial infections can cause death [10].

In the kidneys that was found damage in the form of congestion with a percentage of $44 \%$ and categorized as moderate damage (Table 1, Figure 1). Congestion is a condition that shows an excess volume of blood in a part of a blood vessel due to too much blood entering the arteries [12].

There was also found damage in the form of inflammatory cell infiltration with a percentage of $76 \%$ and categorized of severe damage (Table 1, Figure 2). According to Mireles et al. [13], cell inflammation is a vascular reaction that results in the delivery of fluids, solutes and cells from the blood circulation to the interstitial tissue in the area of injury or necrosis. Inflammation or inflammatory reactions are important mechanisms needed by the body to defend itself from 
various dangers that disturb the balance, also improve the structure and disruption of tissue functions arising from these hazards. Inflammation is characterized by the transfer of fluid from plasma proteins and leukocytes from the blood circulation to the tissues in response to danger. Histopathologically, inflammation is characterized by infiltration of inflammatory cells.

E. coli infects the kidneys through food or drink that is given in the chicken coop, as it is known that chickens dispose of feces carelessly, so $E$. coli contaminates the chicken food and drink. The mechanism of infection of $E$. coli to the kidneys through several stages starts from the process of contamination of ureteral cells by pathogens originating from the intestine followed by the process of bacterial colonization and the process of migrating a small portion of bacteria to the cloaca by using flagella and pili. Then in the cloaca epithelium, some bacterial colonies attach or adhere to the epithelium receptor and excrete toxins and protease enzymes to release nutrients from host cells which are then used as a source of nutrient intake for metabolizing [13].

In addition to producing toxins and enzymes, bacteria also produce siderophore to obtain mineral intake. During the attachment process, the cell's immune system is active and tries to eliminate bacteria, but if bacterial strains have strong defense abilities, such as very fast growth the presence of resistant genes, the immune system's elimination mechanism has no significant effect. After the host immune cells are weak, the bacteria migrate back to the kidneys through the bloodstream and attach to the kidney epithelial cells, colonizing and damaging kidney tissue through the production of toxins and enzymes. Bacteria colonize and most of the colonies of other bacteria migrate to other cells with abundant nutrients through the bloodstream including to muscle cells [14].

\section{CONCLUSION}

Histopathological identification in dead laying hens (Gallus gallus domesticus) suffering from colibacillosis showed damages namely $46 \%$ of degeneration, $60 \%$ of necrosis, $44 \%$ of congestion and $76 \%$ of inflammatory cell infiltration in the kidney tissues.

\section{REFERENCES}

[1] Tabbu. 2000. Penyakit Ayam dan Penanggulangannya. Yogyakarta: Penerbit Kanisius.

[2] Charlton, B.R., A.B. Bermudez, M. Boulianne, D.A. Halvorson, J.S. Jeffrey, L.J. Newman, J.E. Sander, and P.S. Wakenell. 2000. Avian Disease Manual. 5ed.
American Association of Avian Pathologists. Pennsylvania, USA.

[3] Vandekerchove, D., P. De-Herdt, H. Laevens, and F. Pasmans. 2004. Colibacillosis in caged layer hens: characteristics of the disease and the aetiological agent. Avian Pathology. 33(1): 117-125.

[4] Lee, M.D. and H.A. Lawrence. 1998. Colibacillosis in a Laboratory Manual for The Isolation and Identification of Avian Pathogen. American Association of Avian Pathologist. Pennsylvania, USA.

[5] Virgiawati, F. 2013. Gambaran Histopatologi Hepar Tikus Putih (Rattus norvegicus) Akibat pemaparan Bakteriosin dan Boraks (Skripsi). Surabaya: Fakultas Kedokteran Hewan. Universitas Airlangga.

[6] Wibawan, I.W.T., S. Setyaningsih, R.D. Soejodono, S. Murtini, dan Z. Ilyas. 2006. Sero-dan Viral Surveilance pada Ayam Kampung di Provinsi Banten. Laporan Penelitian.

[7] Akoso, B. T. 1998. Kesehatan Unggas. Yogyakarta: Penerbit Kanisius.

[8] Jean, R. 2010. Pengaruh Pemberian Teh Hitam (Camellia sinensis) terhadap Gambaran Histopatologi Ginjal Mencit Balb/C. Fakultas Kedokteran Semarang: Universitas Diponegoro.

[9] Junqueira, L.C., J. Carneiro, dan R.O. Kelley. 2007. Histologi Dasar. Edisi Ke-8. Jakarta: EGC.

[10] Suyanti, L. 2008. Gambaran Histopatologi Hati dan Ginjal Tikus Pada Pemberian Fraksi Asam Amino Non-Protein Lamtoro Merah (Acacia villosa) pada Uji Toksisitas Akut. Bogor: Fakultas Kedokteran Hewan Institut Pertanian.

[11] Berata, I.K., I.B.O.Winaya, A.A.A.M. Adi, dan I.B.W. Adnyana. 2014. Patologi Veteriner Umum. Denpasar: Fakultas Kedokteran Hewan Universitas Udayana.

[12] Julio, E., H. Busman. dan N. Nurcahyani. 2013. Struktur Histologis Hati Mencit (Mus musculus L.) sebagai Respon Terhadap Kebisingan. Jurusan Biologi FMIPA Universitas Lampung.

[13] Mireles N.M., J.R. Johnson, B. Johnston, R. Curtiss and M. Mellata. 2015. Zoonotic potential of Escherichia coli isolates from retail chicken meat products and eggs. Appl Environ Microbiol. 81(3):1177-1187. https:// doi.org/10.1128/AEM.035214 PMID: 25480753.

[14] Nielubowicz G.R. and H.L. 2010. Mobley Hostpathogen interactions in urinary tract infection. Nature Rev Urol. 7: 430-441. This review compares the strategies used by two important uropathogens, E. coli and P. mirabilis, the host response to each pathogen, and the current treatments and therapies to prevent UTIs. [PubMed: 20647992] 